\title{
Obituary to Ian Matthew Campbell
}

Ian Matthew Campbell died on his 46th birthday, 7 December 1987. His death was not entirely unexpected and followed a period of several years in which he was often ill and receiving treatment. From mid September, Ian was unable to work and spent time either in hospital, his own home or in the home of a dear friend. In the last weeks of his life Ian experienced much pain. It seemed appropriate, however, that Ian died in his own bed, at his own home in Clifton Hill.

Ian was always warmly welcoming and generous in his professional relationships with his students and his colleagues, but one was also aware that Ian was an intensely private and modest person. Ian's personal attributes could for this reason go unnoticed. This obituary deals, as it should, with his respected contributions to the profession of clinical psychology. However, his remarkable strengths were not simply academic; for those of us who had a very dear affection for him, they were his impeccable integrity and loyalty, his canny feel for the human condition and his sense of fun.

Most readers would know Ian in his role of Senior Lecturer in the Department of Psychology at the University of Melbourne. Ian moved to Melbourne from Christchurch, New Zealand in 1970. In New Zealand he had trained and worked as a clinician at Sunnyside Hospital. At Melbourne University, Ian was first employed as a tutor and then soon appointed to the position of lecturer to teach behavioural psychology in the soon to be founded Behavioural Research and Therapy Unit. Ian will be remembered by many as the person who introduced rational-emotive therapy (RET) to Australia. His initial contact with RET was somewhat accidental - he described how he had come across Ellis' book $A$ Guide to Rational Living (it was the Guide then, he joked, not the New Guide...) and was struck by its forceful and powerful argument. From the mid-seventies, Ian nurtured a commitment to the rationalemotive model of emotional disturbance among many novitiate clinicians.

As mentioned, Ian was a driving force behind clinical training at Melbourne. He brought to the program expertise in psychological assessment, diagnostics and psychopathology as well as the theory and practice of both behavioural and cognitive approaches. Moreover, Ian communicated a methodology for clinical psychology and promoted strongly the scientist-practitioner model. Many prospective clinicians, with a variety of orientations, sought the Melbourne program because of Ian's reputation as an excellent teacher and a professional role model.

At Melbourne, Ian undertook studies for a $\mathrm{PhD}$, a project looking to the psychometrics of broad-spectrum personality inventories (The Joint Domain of the MMPI and the $C P I)$. His thesis was accepted in 1978 and received high acclaim from examiners including Jack Block and reviewers including Harrison Gough. The large data base was to be utilised subsequently by numerous Honours and Masters candidates. Research, however, was not Ian's greatest strength. In particular, Ian would readily draw the somewhat ironical parallels among the modal publication rate of Clinical Master's theses, his emphasis on accountability and his own record of publication. As a researcher, Ian was especially self-critical - unfairly so. Throughout his years in the Department, Ian consistently attracted graduates with impressive academic records: the demand for his supervision frequently exceeded his availability. Within the University, it is well-recognised that Ian became a more confident researcher; his competence was never doubted. One of the tragedies of Ian's death was that he had begun to make significant contributions both theo- 
retically and empirically to RET and he had initiated a large scale prospective study on the psychosocial factors associated with the Human Immunodeficiency Virus. The standard of that latter work was such that it was awarded funding at both Commonwealth and State levels including the prestigious NHMRC.

Ian's contribution to the Department was multifaceted. For example, in spite of deteriorating health, he presented a Departmental colloquium in August. He believed colloquiums to be an academic's duty; Ian was not only a regular presenter but an active participant. He was in many other ways someone who gave the Department energy and spirit.

His professional work extended well beyond the University. The demand for Ian as a private therapist also exceeded his availability. Ian was a consultant to the Jenny Craig Weight Loss organisation where he devised their Behavioural Education program, authored several staff training manuals, presented lectures and seminars throughout Australia and New Zealand. I know that he was not only a valuable part of that organisation but held in the highest regard for his professionalism and personal integrity. Ian was also involved with Ansett Airlines on projects concerning staff selection and treatment of flight phobias, was a consultant to the Victorian Police Department on hostage taking and negotiation, ran workshops for professionals and the public on topics ranging from his own work on the MMPI and the CPI, rational-emotive therapy, terrorism and sexuality. Frequently Ian would be asked to comment on the psychology of gambling, spider phobias, depression, parenting skills and aversive conditioning. Newspaper clippings record lan's articulate commentaries and demonstrate his ability to recommend common-sense solutions to a variety of different problems.

Further mention should be made of Ian's pre-Melbourne days in order to offer a fuller understanding of his professional attitudes. Ian would describe his youth and student days colourfully. He liked to give the impres- sion that at school he was something of a 'lad' (apparently this was a term his mother affectionately used), who preferred surf beaches and an active social life to studious pursuits. In a typically lan way, he would mischievously reveal his life as an apprentice motor mechanic, his days of training to be a primary school teacher and subsequent teaching over a few years, his holiday and casual employment as a crane operator and a postman. I think the story goes that at university he fortuitously chose psychology because of a favourable lecture timetable which would allow him to maintain such parttime work. These details could be discussed in terms of more accurate chronology; I believe they have more relevance to one of Ian's favourite concepts, namely the importance of being 'street-wise'. Ian deliberately engineered opportunities for his students to discover first-hand the attitudes, emotions and behaviours of people not ordinarily met given our typically restricted beliefs, moral values, social and family networks. Ian was certainly street-wise and in part this was one aspect which contributed to his appeal and success as a clinician.

Over a period of ten years I was fortunate to work with Ian as a casual research assistant, to have his supervision of my Honours, Masters and Doctoral theses, to later become his colleague in the Psychology Department and to be a co-investigator on his AIDS project. Much more valuable than any one of those relationships was the opportunity to be his friend.

To be with Ian socially invariably meant a time of entertainment and fun; often he would show his appreciation of music, dance, literature, food, wine, and his love of people. Sometimes also to be with Ian meant a time of intensity and argument. My memories of such times are precious for Ian was a person who reserved his passions. Any awkwardness experienced the 'morning after' would be quickly dispelled; Ian responded to these occasions always with his sense of humility and his 'get on with life' philosophy.

Ian gave his advice to many who sought 
it in troubled times, and they included clients, students, fellow staff members as well as friends and family, and he encouraged them to set personal goals which otherwise would be dreams. And it is among these people where Ian's legacy can be found. A generation of clinical psychologists will look to their memories of, and time with, Ian to inspire them in their work. His personal standards and humanity will be examples to all. Like many who were privileged to know him, I know how much richer my life has been because of Ian Campbell.

Philip Burgess

Pleasant View Centre

131 Wood Street

Preston 3072 